\title{
СОЦИАЛЬНО-ЭКОНОМИЧЕСКИЕ УСЛОВИЯ ПОВЫШЕНИЯ КАЧЕСТВА ТРУДОВОЙ ЖИЗНИ В СОВРЕМЕННОЙ РОССИИ
}

\author{
О. И. Меньшикова \\ Московский гуманитарный университет
}

Аннотация: Рассматривается комплекс социально-экономических условий повышения качества трудовой жизни с позищий различных участников трудовых отношений. Показана взаимосвязь государственной и корпоративной социальной политики в процессе достижения более высоких показателей качества трудовой жизни в России.

Ключевые слова: качество трудовой жизни; социально-трудовые отношения; социальная политика; социальное партнерство

\section{SOCIAL AND ECONOMIC CONDITIONS FOR IMPROVING THE QUALITY OF WORKING LIFE IN MODERN RUSSIA}

\author{
O. I. Menshikova \\ Moscow University for the Humanities
}

\begin{abstract}
The paper considers the complex of social and economic conditions of improving the quality of working life from the standpoint of various participants of labor relations. It shows the correlation between the state and corporate social policy in the process of achieving higher indicators of quality of working life in Russia.

Keywords: quality of working life; social and labor relations; social policy; social partnership

Мировая практика и проводимые научные исследования показывают, что обеспечение определенного качества трудовой жизни является одной из приоритетных задач стабилизации и развития экономики любой страны. При этом концепция качества трудовой жизни, разработанная в США и странах Западной Европы, ориентирована в основном на социальные аспекты обеспечения трудовой деятельности. Высокие темпы научно-технического прогресса в 60-70-е годы XX века предопределили необходимость кардинального пересмотра ранее существующих подходов к определению места и роли человека в современном трудовом и производственном процессах.

В современном обществе качество трудовой жизни является одной из основных характеристик социально-трудовых отношений. «Качество трудовой жизни - это интегральное понятие, всесторонне характеризующее уровень и степень благосостояния, социального и духовного развития чело-
\end{abstract}


века через его деятельность в организации. Качество трудовой жизни выступает основным показателем оценки социально-трудовых отношений» (Шлендер, Кокин, 2003: 524). Вместе с тем, в процессе социально-трудовых отношений, характеризующих экономические, психологические и правовые аспекты взаимосвязей индивидуумов и социальных групп в процессах, обусловленных трудовой деятельностью, формулируется ряд основных условий, обеспечивающих качество трудовой жизни. К числу таких условий относятся: надлежащее и справедливое вознаграждение за труд; безопасные и здоровые условия труда; благоприятный климат для самовыражения и самореализации работников; обеспечение трудовой демократии и правовой защищенности; создание условий для профессионального роста; придание социальной полезности выполняемой работе и др.

Таким образом, путем определенных воздействий на характер социально-трудовых отношений может быть создан соответствующий механизм, регулирующий качество трудовой жизни и способствующий его росту. Наиболее гибкий характер социально-трудовых отношений присущ коллективно-договорным отношениям, формирующимся в рамках системы социального партнерства.

Как известно, в основе социального партнерства лежит «трипартизм», отражающий саму его суть - систему взаимоотношений между работниками (представителями работников), работодателями (представителями работодателей), органами государственной власти, органами местного самоуправления, направленную на обеспечение согласования интересов работников и работодателей по вопросам регулирования трудовых отношений и иных непосредственно связанных с ними отношений (Трудовой кодекс РФ. Ст. 23; см.: Трудовой кодекс ... , Электр. ресурс). При этом проблемы качества трудовой жизни занимают ведущее место в системе взаимоотношений социальных партнеров.

Таблица 1. Распределение «ролей» социальных партнеров в обеспечении соответствующего качества трудовой жизни

\begin{tabular}{|c|c|c|c|}
\hline \multirow[t]{2}{*}{$\begin{array}{l}\text { Основные составляющие } \\
\text { качества трудовой жизни }\end{array}$} & \multicolumn{3}{|c|}{$\begin{array}{c}\text { Потенциальные возможности социальных партнеров в обеспечении со- } \\
\text { ответствующего качества трудовой жизни }\end{array}$} \\
\hline & Государство & Работодатели & Работники \\
\hline $\begin{array}{l}\text { Условия труда и быта на ра- } \\
\text { бочем месте (техническая } \\
\text { оснащенность, санитар- } \\
\text { но-гигиенические условия) }\end{array}$ & $\begin{array}{l}\text { - разработка государ- } \\
\text { ственных программ } \\
\text { механизации и авто- } \\
\text { матизации производ- } \\
\text { ства; } \\
\text { - стимулирование на- } \\
\text { учных разработок в } \\
\text { области инновацион- } \\
\text { ных технологий }\end{array}$ & $\begin{array}{l}\text { - своевременное обнов- } \\
\text { ление средств и пред- } \\
\text { метов труда; } \\
\text { - внедрение новых тех- } \\
\text { нологий производства; } \\
\text { - создание эргономич- } \\
\text { ных рабочих мест }\end{array}$ & $\begin{array}{l}\text { - стремление к освое- } \\
\text { нию новых техноло- } \\
\text { гий; } \\
\text { - соблюдение трудовой } \\
\text { дисциплины; } \\
\text { - бережное отношение } \\
\text { к оборудованию рабо- } \\
\text { чего места }\end{array}$ \\
\hline
\end{tabular}




\begin{tabular}{|c|c|c|c|}
\hline \multirow[t]{2}{*}{$\begin{array}{l}\text { Основные составляющие } \\
\text { качества трудовой жизни }\end{array}$} & \multicolumn{3}{|c|}{$\begin{array}{c}\text { Потенциальные возможности социальных партнеров в обеспечении со- } \\
\text { ответствующего качества трудовой жизни }\end{array}$} \\
\hline & Государство & Работодатели & Работники \\
\hline $\begin{array}{l}\text { Охрана и безопасность тру- } \\
\text { да }\end{array}$ & $\begin{array}{l}\text { - управление охраной } \\
\text { труда; } \\
\text { - достойная компен- } \\
\text { сация за неблагопри- } \\
\text { ятные условия труда }\end{array}$ & $\begin{array}{l}\text { - выполнение законо- } \\
\text { дательных требований } \\
\text { по охране и безопасно- } \\
\text { сти труда; } \\
\text { - разработка профи- } \\
\text { лактических мер по } \\
\text { снижению травматиз- } \\
\text { ма и профессиональ- } \\
\text { ных заболеваний }\end{array}$ & $\begin{array}{l}\text { - соблюдение техники } \\
\text { безопасности; } \\
\text { - внесение рационали- } \\
\text { заторских предложе- } \\
\text { ний по совершенство- } \\
\text { ванию охраны труда на } \\
\text { предприятии }\end{array}$ \\
\hline Оплата труда & $\begin{array}{l}\text { - разработка и обе- } \\
\text { спечение минималь- } \\
\text { ных гарантий оплаты } \\
\text { труда; } \\
\text { - выработка критери- } \\
\text { ев достойной оплаты } \\
\text { труда; } \\
\text { - определение на- } \\
\text { правлений совершен- } \\
\text { ствования форм и } \\
\text { систем оплаты труда; } \\
\text { - мониторинг оплаты } \\
\text { труда в отдельных } \\
\text { сферах экономиче- } \\
\text { ской деятельности; } \\
\text { - управление тру- } \\
\text { довой миграцией в } \\
\text { целях недопущения } \\
\text { злоупотреблений на } \\
\text { рынке труда }\end{array}$ & $\begin{array}{l}\text { - разработка систе- } \\
\text { мы стимулирования } \\
\text { и мотивации труда в } \\
\text { конкретной сфере эко- } \\
\text { номической деятель- } \\
\text { ности; } \\
\text { - недопущение задер- } \\
\text { жек по выплате зара- } \\
\text { ботной платы; } \\
\text { - своевременная ин- } \\
\text { дексация заработной } \\
\text { платы }\end{array}$ & $\begin{array}{l}\text { - получение качествен- } \\
\text { ного профессиональ- } \\
\text { ного образования; } \\
\text { - дополнительное об- } \\
\text { разование в целях по- } \\
\text { вышения конкуренто- } \\
\text { способности на рынке } \\
\text { труда; } \\
\text { - инициирование дей- } \\
\text { ствий профсоюзов по } \\
\text { защите прав работ- } \\
\text { ников на достойную } \\
\text { оплату труда }\end{array}$ \\
\hline $\begin{array}{l}\text { Правовая защищенность и } \\
\text { гарантии занятости }\end{array}$ & $\begin{array}{l}\text { - совершенствование } \\
\text { трудового законода- } \\
\text { тельства; } \\
\text { - контрольно-надзор- } \\
\text { ная деятельность в } \\
\text { трудовой сфере }\end{array}$ & $\begin{array}{l}\text { - беспрекословное ис- } \\
\text { полнение норм трудо- } \\
\text { вого права; } \\
\text { - недопущение дис- } \\
\text { криминации на рынке } \\
\text { труда }\end{array}$ & $\begin{array}{l}\text { - повышение уровня } \\
\text { юридической и эконо- } \\
\text { мической грамотно- } \\
\text { сти; } \\
\text { - повышение качества } \\
\text { рабочей силы на осно- } \\
\text { ве компетентностного } \\
\text { подхода }\end{array}$ \\
\hline Социальная защищенность & $\begin{array}{l}\text { - разработка страте- } \\
\text { гии преодоления бед- } \\
\text { ности трудоспособно- } \\
\text { го населения; } \\
\text { - социальная под- } \\
\text { держка семей с деть- } \\
\text { ми; } \\
\text { - совершенствование } \\
\text { системы пенсионного } \\
\text { обеспечения и соци- } \\
\text { ального страхования; } \\
\text { - повышение статуса } \\
\text { людей труда }\end{array}$ & $\begin{array}{l}\text { - разработка корпора- } \\
\text { тивных социальных } \\
\text { программ; } \\
\text { - недопущение массо- } \\
\text { вого высвобождения } \\
\text { работников; } \\
\text { - открытость коммуни- } \\
\text { каций и информации, } \\
\text { необходимой работни- } \\
\text { кам }\end{array}$ & $\begin{array}{l}\text { - повышение социаль- } \\
\text { ной активности работ- } \\
\text { ников; } \\
\text { - повышение социаль- } \\
\text { ной ответственности } \\
\text { работников за благосо- } \\
\text { стояние своей семьи }\end{array}$ \\
\hline
\end{tabular}




\begin{tabular}{|c|c|c|c|}
\hline \multirow[t]{2}{*}{$\begin{array}{l}\text { Основные составляющие } \\
\text { качества трудовой жизни }\end{array}$} & \multicolumn{3}{|c|}{$\begin{array}{c}\text { Потенциальные возможности социальных партнеров в обеспечении со- } \\
\text { ответствующего качества трудовой жизни }\end{array}$} \\
\hline & Государство & Работодатели & Работники \\
\hline $\begin{array}{l}\text { Социально-психологиче- } \\
\text { ский климат }\end{array}$ & $\begin{array}{l}\text { поддержание имиджа } \\
\text { социального государ- } \\
\text { ства }\end{array}$ & $\begin{array}{l}\text { соблюдение принци- } \\
\text { пов корпоративной со- } \\
\text { циальной ответствен- } \\
\text { ности; } \\
\text { - стиль руководства, } \\
\text { обеспечивающий ува- } \\
\text { жение к личности; } \\
\text { - обеспечение благо- } \\
\text { приятных условий для } \\
\text { карьерного роста со- } \\
\text { трудников; } \\
\text { - разработка и внедре- } \\
\text { ние программ повыше- } \\
\text { ния квалификации }\end{array}$ & $\begin{array}{l}\text { - соблюдение требо- } \\
\text { ваний корпоративной } \\
\text { этики; } \\
\text { - повышение мотива- } \\
\text { ции профессиональ- } \\
\text { ной деятельности; } \\
\text { - соучастие в принятии } \\
\text { управленческих реше- } \\
\text { ний; } \\
\text { - готовность работ- } \\
\text { ников идти ради } \\
\text { сохранения и процве- } \\
\text { тания организации на } \\
\text { некоторые разумные } \\
\text { издержки ит.д. }\end{array}$ \\
\hline
\end{tabular}

В таблице 1 четко прослеживается объективная взаимосвязь и взаимозависимость так называемых «ролей» социальных партнеров в процессе формирования и развития соответствующего качества трудовой жизни. В рамках социально-трудовых отношений посредством коллективно-договорного регулирования происходит согласование интересов работодателей и работников при участии государства на всех уровнях системы социального партнерства: федеральном, региональном, отраслевом, локальном.

При этом следует понимать, что ресурсы, которыми обладают социальные партнеры, различны.

Таблица 2. Основные ресурсы, которыми обладают субъекты социального партнерства

\begin{tabular}{|c|c|}
\hline Субъекты & Ресурсы \\
\hline Работники & $\begin{array}{l}\text { Набор моделей коллективных и индивидуальных форм выра- } \\
\text { жения требований }\end{array}$ \\
\hline Работодатели & $\begin{array}{ll}\cdot & \text { Административно-правовые рычаги } \\
\cdot & \text { Экономические ресурсы } \\
\bullet & \text { Политические рычаги } \\
\text { • } & \text { Социально-психологические механизмы }\end{array}$ \\
\hline Государство & $\begin{array}{ll}\cdot & \text { Законодательные акты } \\
\cdot & \text { Налоговые рычаги } \\
\cdot & \text { Административные рычаги } \\
\text { • } & \text { Политические и социально-психологические механизмы }\end{array}$ \\
\hline
\end{tabular}

Соответственно, очень важно, какую социальную политику в отношении трудоспособного населения реализуют в своей деятельности госу- 
дарственные органы и представители бизнес-сообщества. В современных российских условиях это особенно актуально, т. к. и в государственной и в корпоративной социальной политике недостаточно внимания уделяется экономически активному населению, осуществляющему трудовую деятельность.

Уже один тот факт, что среди бедного населения России преобладают трудоспособные граждане, говорит о многом. В рыночных условиях оплата труда является важнейшим индикатором качества трудовой жизни. От удовлетворенности заработной платой во многом зависит удовлетворенность трудом вообще и качеством трудовой жизни, в частности.

Основные направления государственной и корпоративной социальной политики в отношении экономически активного населения - главного носителя трудового потенциал общества должны состоять в следующем:

1. Признание экономически активного населения не только субъектом, но и объектом социальной политики в интересах защиты данной категории от социальных рисков на рынке труда;

2. Повышение уровня государственных социальных гарантий в области оплаты труда;

3. Разработка дополнительных мер государственной поддержки семей с детьми;

4. Развитие и совершенствование корпоративных социальных программ, направленных на активизацию человеческого фактора и повышение экономической активности населения;

5. Синхронизация мер государственной и корпоративной социальной политики на основе конструктивного взаимодействия социальных партнеров и развития гражданского общества.

\section{СПИСОК ЛИТЕРАТУРЫ}

Трудовой кодекс Российской Федерации от 30.12.2001 № 197-Ф3 (ред. от 05.02.2018) [Электронный ресурс] // КонсультантПлюс. URL: http://www. consultant.ru/document/cons_doc_LAW_34683/ (дата обращения 02.07.2018).

Шлендер, П. Э., Кокин, Ю. П. (2003) Экономика труда : учебник. М.: Юристъ. 592 с.

Дата поступления: 15.09.2018 г.

Меньшикова Ольга Ивановна - доктор экономических наук, профессор кафедры экономических и финансовых дисциплин Московского гуманитарного университета. Адрес: 111395, Россия, г. Москва, ул. Юности, д. 5. Тел.: +7 (499) 374-73-61. Эл. адрес: om-g@yandex.ru 
Menshikova Olga Ivanovna, Doctor of Economics, Professor, Department of Economic and Financial Disciplines, Moscow University for the Humanities. Postal address: 5, Yunosti St., Moscow, Russian Federation, 111395. Tel.: +7 (499) 374-7361. E-mail: om-g@yandex.ru

\section{Для цитирования:}

Меньшикова О. И. Социально-экономические условия повышения качества трудовой жизни в современной России [Электронный ресурс] // Научные труды Московского гуманитарного университета. 2018. № 5. URL: http://journals.mosgu.ru/trudy/article/view/824 (дата обращения: дд.мм.гг.). DOI: $10.17805 /$ trudy.2018.5.4 